\title{
Translation and a politics of forgiveness in South Africa? What black Christians believe, and white Christians do not seem to understand
}

\author{
Dion Angus Forster \\ Stellenbosch University, South Africa \\ dionforster@sun.ac.za
}

\begin{abstract}
Why would white South Africans want to be forgiven? Is it in order to secure their future, or to escape from their past? Why is it that some black South Africans find forgiveness to be impossible in the current social and political reality? Forgiveness, as a theological and social discourse in South Africa, is deeply contested. This research shows that black and white South Africans understand notions, and processes of forgiveness in very different ways. This is a significant problem that is compounded by the legacy of ongoing structural injustice as a result of Apartheid. Un-reconciled persons in South Africa seldom have contact with each other since the apartheid system separated persons racially, according to economic class and geographically. In at least one sense this makes a shared understanding of, and approach to, forgiveness impossible. To some extent, South Africans do not truly encounter one another in meaningful engagement, or in spaces of shared meaning. In other words, there is both a hermeneutic and a social barrier to forgiveness in South Africa. Paul Ricoeur's notion of translation can help to engage the complexities that exist in language and the very nature of the difference between the self and the other in what is termed a "politics of forgiveness".
\end{abstract}

Key words

Ricoeur; forgiveness; politics; ethics; South Africa; systematic theology

\section{Introduction}

From where do you speak? This is a deeply contextual question. It is particularly pertinent in South Africa at present which is divided along the lines of race, economics, and social class. It would be a mistake to say that 
say that one can speak from a South African perspective. In truth, there is no single South Africa from which to speak - there are multiple South Africa's (at least in relation to experience and identity) (Mbembe 2008: 6, 2015). These multiple South Africa's are upheld by the varied social identities, aspirations, and experiences of South Africans (Forster 2017a: 1-3; 214218). Within the context of this diversity of identity and perspective, this article argues for the development of an (im)possible politics of forgiveness among South Africans. The constituent terms, related to this argument, will be explained and clarified as a point of departure. Next, aspects of Paul Ricoeur's philosophy of translation will be considered in relation to this (im)possible politics of forgiveness among South Africans.

\section{On forgiveness and translation}

Forgiveness, as a theological and social discourse in South Africa, is deeply contested. Numerous South African scholars and activists have raised concerns about the transactional nature of the concept of forgiveness in this context (cf., Gobodo-Madikizela \& Merwe 2009; Vosloo 2015a, 2012). Why would white South Africans want to be forgiven? Is it to deal with the 'sins' of their apartheid past? Or is forgiveness intended to offer a future that is free from the necessity for reparation and restoration in the present? Why do so many black South Africans view forgiveness with suspicion and distrust? As will be shown, black and white South Africans have very different understandings of the concepts and requirements of forgiveness.

Interpersonal socio-political factors, such as the nature of the historical offences of apartheid, whether reparation has been made (or attempted) for these offences, the political identities of the parties involved, expectations and conditions for the self and for the other, also play a role in understandings of forgiveness. One significant problem that has been identified, and is evidenced in the findings of this research, is that un-reconciled persons in South Africa seldom have contact with each other because of the legacy of the apartheid system which separated persons racially, according to economic class, and geographically (Hofmeyr \& Govender 2015: 1). In at least this sense forgiveness remains improbable, even impossible, among South Africans. Not only is it impossible for persons to forgive one another since they have no proximate or authentic social engagement, forgiveness 
is also a theological impossibility because of deeply held and entrenched faith convictions about the nature and processes of forgiveness, which are frequently in conflict with one another. Richard Kearney might say that we lack an adequately developed "carnal hermeneutics" for the task (Kearney 2007: 151-152, 2015: 99-100). We face both hermeneutic and social barriers to forgiveness in South Africa. Yet, since almost $85 \%$ of South Africans indicate that they are Christian (cf., Schoeman 2017: 1-7), and forgiveness is so important in Christianity, we cannot simply give up on this contested concept (Forster 2017a: 17-18).

Paul Ricoeur's work is helpful in this context - as Vosloo states, it offers both hermeneutic and mediating possibilities (Vosloo 2015b: 1). Ricoeur's approach helps because he suggests that what is needed is an approach to translation that can bridge the differences in language, and also the very nature of the difference between the self and the other (Ricoeur \& Brennan 1995: 7). He writes,

"[t]ranslation can be understood here in both a specific and a general sense. In the specific sense - the one in common contemporary usage - it signals the work of translating the meanings of one particular language into another. In the more generic sense, it indicates the everyday act of speaking as a way not only of translating oneself (inner to outer, private to public, unconscious to conscious, etc.) but also more explicitly of translating oneself to others." (Ricoeur 2007a: xiv-xv).

In other words, translation can facilitate a measure of shared understanding, and shared meaning, of what the term forgiveness connotes when it is used in communication between persons. Kearney describes this form of translation as the linguistic paradigm (Kearney in Ricoeur 2007b: xii). In addition to this understanding Kearney describes an additional form of translation. He calls this the ontological paradigm - "how translation occurs between one human self and another" (Kearney in Ricoeur 2007b: xii). Behind this second understanding of translation lies Ricoeur's conception of how identity is constructed, and has the possibility of being reconstructed. "The identity of a group, culture, people or nation, is not that of an immutable substance, nor that of a fixed structure, rather, of a recounted story" (Ricoeur \& Brennan 1995: 7). 
Individual identities, and social identities, are connected to memory through constructed narratives, i.e., the way in which we communicate ourselves to others by means of sharing what we remember, understand, and believe from our individual and collective past (Dube 2017:120-121). As Dube suggests, "representations of history and identity regularly find shifting yet salient configurations - as contested territory, ambivalent resource, ready motif, and settled verity - within public discourses" (Dube 2017: 121). In such a contested space forgiveness requires both linguistic and ontological translation if it is to have any constructive value for society. In relation to this Nussbaum writes:

"[T]he ability to imagine the experience of another - a capacity almost all human beings possess in some form - needs to be greatly enhanced and refined if we are to have any hope of sustaining decent institutions across the many divisions that any modern society contains." (Nussbaum 2010: 10).

The notion of ontological translation, which is central to this task, is developed further by Ricoeur in his work on forgiveness. He highlights the complexities both of engaging differing understandings of forgiveness, and working towards states of forgiveness. Translation accentuates the "complexities involved in forgiving in a way that resists cheap forgiveness" (Vosloo 2015a: 360). Cheap forgiveness is the kind of forgiveness that either collapses the identity of the other into a notion of the self, or sets the self free from guilt without any remainder to the expectation and experience of the other. It is for this reason that this paper speaks of a 'politics of forgiveness'. Black and white South Africans, as we shall see, construct their understandings of forgiveness in quite different ways.

\section{What black Christians believe and white Christians don't seem to understand.}

The title for this paper originates from the findings of a four-year long research project on forgiveness that was conducted with black and white Christians in Cape Town, South Africa ${ }^{1}$. The research aimed to ascertain,

1 Please see, (Forster: 2017a). The (im)possibility of forgiveness? An empirical intercultural Bible reading of Matthew 18:15-35. 1st ed. Vol. XI. Beyers Naudé Centre Series on Public Theology (Stellenbosch, South Africa: SUN Press). 
by means of a qualitative empirical study, how a sampling of black and white South African Christians understand forgiveness. What does forgiveness mean? What does each group understand as the expectations, processes and requirements for forgiveness to be realised?

South African society remains deeply divided. The fault lines of division are particularly evident in the Christian Church. If one were to visit a Church gathering on a Sunday one would find that in large measure the hegemonic identities of race, class, culture, economics and theology, are deeply entrenched and maintained (van der Borght 2009: 9). While South Africans have had to learn to live and work together in certain public spaces, such as workplaces and schools, there is no such pressure, or expectation, for unity, or at least engagement in diversity, within the Church. This is telling, since it seems to expose that when persons have the privilege of choice as to whom they will associate with, they choose not to encounter difference, but rather to retreat to the safety of the familiar. Black Christians and white Christians have separate spaces of worship, different cultures, liturgies, languages, and even theologies. These are largely related to their respective social identities, which are deeply shaped by South Africa's history of colonialism and apartheid.

Speaking at the occasion of receiving an honorary doctorate at Stellenbosch University in March 2018, the former Rector of the University of the Western Cape, Prof Brian O'Connell said of South African society, that "the absence of sense making [among South Africans] is causing huge suffering". He was imploring the gathered graduates to use their intellect and acquired skills to help South Africans to make sense of the realities that we continue to face more than two decades after the end of political apartheid. If we could help one another not only to recognise how our society is constructed (socially, economically, politically), but also to gain some understanding of the values, commitments, and reasoning that hold such systems in place ${ }^{2}$ - what he referred to as "sense making" - we could

2 Francis Fukuyama offers a very insightful discussion of the construction of polarized identities in contemporary societies in his book Identity: The Demand for Dignity and the Politics of Resentment, cf., (Fukuyama: 2018: 3-12). Conversely, Kwame Appiah questions the weight that is placed on political identity construction as a primary category in contemporary studies on social identity complexity in his book, The Lies That Bind: Rethinking Identity, cf., (Appiah: 2018: 1-32). 
unmask the systems, and beliefs, that perpetuate suffering. We shall touch on this later, but this is a crucial aspect of what Ricoeur calls an "exchange of memories" that could "shatter the debt" of our traumatic past and unjust present realities (Ricoeur \& Brennan 1995: 10). Homi Bhabha further develops this notion in what he characterises as the, "healing of history, a community reclaimed in the making of a [new] name" (Bhabha 2012: 17).

It could be said that forgiveness is an 'insensible' notion. Because of the debts of the past, and unhealed history, discourses of forgiveness frequently contribute towards the ongoing suffering of South Africans. Insensible, as it is used here, signifies the sense of a lack of awareness of meaning, or apathy to other possible meanings. We simply have not done enough "sense making" with one another, as black and white Christians, to plumb the depths of an authentic, "difficult forgiveness" (Vosloo, 2015a: 360). The South African poet, Nathan Trantraal, in his poem Fiction en enstrangement tells of how after the 1994 Democratic elections in South Africa, the Christian religion called upon black South Africans to be "Christlike", to give up the violent struggle for liberation, and to forgive their white perpetrators for the sins of apartheid. Yet, Trantraal says that it resulted in a cheap forgiveness - forgiveness without justice. He writes:

Ammel het hystoe gegan

Hulle na hulle hyse langsie sea

ós na ós shacks

langs poeletjies stagnant wate

waa die gif in vergifnis

ós ammel

siek gemaak et

Trantraal says this cheap forgiveness made everyone sick. He employs a subtle play on the Afrikaans words for forgiveness and poison to do so, pointing to the "gif [poison] in vergifnis [forgiveness]" (cf., "Alles het niet kom wôd deur Nathan Trantraal" 2017; Trantraal 2017). This sentiment is evidenced in the 2015 Institute for Justice and Reconciliation (IJR) report on reconciliation, which notes that:

"While most South Africans agree that the creation of a united, reconciled nation remains a worthy objective to pursue, the country remains afflicted by its historical divisions. The majority feels that 
race relations have either stayed the same or deteriorated since the country's political transition in 1994 and the bulk of respondents have noted income inequality as a major source of social division. Most believe that it is impossible to achieve a reconciled society for as long as those who were disadvantaged under apartheid remain poor within the 'new South Africa'" (Hofmeyr \& Govender 2015: 1).

What the research on forgiveness among black and white South Africans found was that social identity, of which political identity is a part (cf., Fukuyama 2018: 3-5), played a very important role in the construction of beliefs concerning the expectations, processes and content of forgiveness.

We cannot go into great detail on the findings of the research at this stage. However, the general findings where that:

- Among the predominantly black / coloured participants, forgiveness was largely understood in a collective and social manner (Forster 2017a: 178-184). In other words, forgiveness was not only an individual concern, it had social consequences and social expectations within the community. Moreover, this group understood that forgiveness was not only a matter of spiritual restoration between the individual (or community) and God. Rather, it should be evidenced in the restoration of relationships and structures in the community. For this group, forgiveness can only be authentic if the conditions for forgiveness are evidenced in the community - in other words, forgiveness in South Africa would be contingent upon economic transformation, transfer of land ownership, a transformation of social power dynamics, and visible and tangible expressions of remorse on the part of the beneficiaries and initiators of apartheid in South Africa. A social understanding of community harmony is largely in keeping with notions of intersubjective identity that are more common in black and Coloured South African communities (Adhikari 2005; Cakal, Hewstone, Schwär \& Heath 2011; Forster 2010a,b; cf., Shutte 2009).

- While the white participants largely understood forgiveness in an individual and spiritual manner (Forster 2017a: 184-189). For the majority of participants in this group, the data showed that they viewed forgiveness as being primarily a matter of restoring their spiritual relationship with God. They did not initially consider that 
forgiveness may need to engage the party against whom the sin (or grievance) was committed. Forgiveness is theological (spiritual) it has to do with spiritual sin. As such, God is the offended party, and forgiveness would have been enacted when God had set them free from the guilt and spiritual culpability of their actions. Such a view of forgiveness would not necessarily entail the restoration of relational harmony among members of the community or the restitution of social, political or economic structures in the community. Common expressions of this view would be statements such as, "apartheid was wrong, but it is over. I confessed my part in [sin] it and I believe God has forgiven me. Now we need to move on and stop living in the past. We must stop talking about apartheid".

At the time of O'Connell's speech I was reading Ricoeur's collection of essays, On translation (Ricoeur 2007b) and, Reflections on a new ethos for Europe (Ricoeur \& Brennan 1995), as well as Memory, History, Forgetting (Ricoeur 2009). I was struck by the coherence between O'Connell's insight and what I was reading in Ricoeur. Indeed, the abovementioned research on understandings of forgiveness among Black and white Christians, seems to show that in South Africa we miss-read, miss-represent, missinterpret, miss-understand, and often simply 'miss' one another altogether. We live with a challenging past, the wounds of which are still felt daily. Yet, because we have lost the capacity for both linguistic and ontological translation (Ricoeur 2007b: xv), we make life impossible for one another. Our lack of sense making increases suffering for the self and others. We find it very difficult to live hospitably with one another's identity, experience, and memory. The result is that we hamper the possibility for a meaningful, shared, existence - we remain in conflict. Within this context, I find the statement of Kearney in the introduction to On Translation, deeply challenging. He says that it, “... is only when we translate our own wounds in the language of strangers and retranslate the wounds of strangers into our own language that healing and reconciliation can take place" (Ricoeur 2007a: xx).

To my mind, this is an essential aspect of our current problem. Black and white South Africans do not understand each other, indeed, we seldom encounter one another in a meaningful way - by that I mean ways in which meaning is filled out, explicated, opened up, shared, translated (in both the linguistic and the ontological senses). 


\section{Why an (im)possible politics of forgiveness?}

There are two important concepts that need some clarification in relation to the previous statement. First, we need to consider the use of the notion of a 'politics' of forgiveness. Why politics? Next, we shall consider the use of the qualifier of 'possibility', or 'impossibility', (expressed in the multifaceted word, (im)possibility), in relation to this politics of forgiveness.

\subsection{A politics of forgiveness}

First, let's ask the question, why a politics of forgiveness? In his book, The politics of peace, Brian Frost suggests that to the popular imagination, linking politics and forgiveness may seem unusual (Frost 1991: 1). Forgiveness would seem to be a deeply theological concept, while politics comes from a much more secular framing of reality. However, as he notes,

" 'Politics' is surely the way human beings organize themselves in groups, either locally, nationally or internationally, to determine and distribute the use of resources, often in short supply, and how they handle the institutions they create for doing this. 'Forgiveness' is a word used to indicate that a wrong has been committed which needs redressing. It is also a word which implies both accepting a wrong and dealing with it in a constructive way." (Frost 1991: 1)

In this regard it the coupling of politics and forgiveness finds a link in both space and time - how we deal with our present reality, must be considered in the light of our experiences of the past, and our hopes for the future. Forgiveness, in this sense, is deeply political. It is a narrative construction of the past that sets forth certain expectations for the self and the other in relation to the future (cf., Andrews 1999: 107-124; Janover 2005: 221-235).

This relates to the contested nature of forgiveness in South Africa. Some political actors would have us believe that the solution to our challenges in South Africa are purely transactional. If the land is returned to those from whom it was unjustly taken, the economy is transformed to the benefit of the majority of our population, and we transform our social and political life to mitigate the legacy of white privilege in South Africa, then all that is necessary for harmony in South Africa would have taken place. I contend that the transactions are not enough. We need this and more, as we shall see in the next section. 
We will not move towards justice or reconciliation until these issues are concretely and clearly dealt with. In this sense, there is a clear political dimension to forgiveness, with expectations and processes, for transformation and justice to be realised in South Africa. As stated previously, the majority of the black participants in the study understood such transactions as necessary precursors for forgiveness. Forgiveness, in this context, is political in the sense that it has concrete structural, requirements, social expectations, and political connotations.

\subsection{An (im)possible politics of forgiveness}

However, the important "sense making" question is whether a mere political, economic, or social transaction goes far enough towards achieving authentic forgiveness? Or, stated more directly, is there more to forgiveness than 'mere' politics? The political transaction is necessary - but it would be a mistake to think that it alone will achieve the desired end. The research data shows that rather constituting the end of forgiveness, the political dimension facilitates the necessary conditions that bring us to the beginning of what could become true, authentic, and transformative forgiveness (Forster 2017a: 214-216). This is where the choice for the notion of an (im)possible politics of forgiveness is deemed helpful.

The use of the phrase "(im)possible" is deliberate. This notion should not be unfamiliar to Ricoeur scholars ${ }^{3}$. However, this particular usage is predicated on Jacques Derrida's use of "im-possible" in his lecture, A Certain Impossible Possibility of Saying the Event (Derrida 2007: 441-461), and also Richard Kearney's discussion of this concept in, Forgiveness as the limit: Impossible or possible (Kearney 2013: 305-320). ${ }^{4}$ What is of importance in this usage of the term is the tension that the phrase creates between what is impossible, and so possible (i.e., the bracketing of what makes the (im)possible, possible). A possibility emerges for a more profound type of forgiveness to take place, precisely because of its dialectic tension with transactional impossibility.

3 See for example, (Ricoeur, 2000), Can forgiveness heal? In H.J. Opdebeeck (ed.). Leuven: Peeters The Foundation and Application of Moral Philosophy: Ricoeur's Ethical Order. 31-36, and (Ricoeur, 2004)The difficulty to forgive. In M. Junker-Kenny \& P. Kenny (eds.). Münster: LIT Verlag, Memory, Narrativity, Self and the Challenge to Think God: The reception with Theology of the Recent work of Paul Ricoeur, 6-18.

4 For a more developed discussion of how this term is developed in relation to the South African context please see (Forster, 2017a: 4-7, 17-18, b: 1-3, 8-9) 
As has been argued above, true forgiveness is a transactional impossibility. How could one ever attach an adequate price to compensate for the violence of apartheid? This does not mean a price must not be paid, but would any sum ever be enough? What possible act, or gesture, could truly account for the dehumanizing consequences of this social and political system? This does not mean that such acts are unimportant, indeed they are crucial and must be undertaken. But will any act ever be enough to address the scale of the wrongdoing that has taken place? What this dialectic between possible/impossibility highlights is the inadequate contingent relationship that some political actors place on mere political, economic, or social recompense. For example, when the majority of South Africans 'own' the land and the economy of South Africa, would this have dealt with all of the horror and brokenness of apartheid? Such a narrow transactional view of forgiveness is not only theoretically inadequate, it also does not address the severity of black pain and white culpability in relation to apartheid. Ricoeur argues that it is precisely the fact that true forgiveness is transactionally impossible, that makes the act of impossible (and exceptional) grace both possible and necessary in forgiveness (cf., Ricoeur 2000: 31-36, 2004: 6-18). This is an act of radical translation.

Just as in linguistic translation, we are "called to make our language put on the stranger's clothes at the same time as we invite the stranger to step into the fabric of our speech", so too should we act in ontological translation (Kearney in Ricoeur 2007b: xvi). The act of hospitality is essential in this regard. Ricoeur speaks of it as follows:

"It is really a matter of living with the other in order to take that other to one's home as a guest... In this sense we can speak of a translation ethos whose goal would be to repeat at the cultural and spiritual level the gesture of linguistic hospitality mentioned above."

(Ricoeur \& Brennan 1995: 5 emphasis in the original).

It is the willingness to live together in the cultural (even spiritual, or theological) milieu "governed by the ethical and spiritual categories of the other" that makes translation possible and meaningful (Ricoeur \& Brennan 1995: 5).

At this point it is necessary to make a brief diversion on an aspect of terminology - in my writing, and whenever I speak, I encourage colleagues not to use the phrase "post-apartheid South Africa" (cf., footnote 7 in Botha 
\& Forster 2017: 2). Although political apartheid ended in South Africa with the first democratic elections on 27 April 1994, the reality is that in the daily experience of most South Africans, apartheid remains very real and present. Economic segregation, racial and spatial (geographic) segregation, racism, and the politics of identity are worse today than they were in 1994. My work with young black activists (many of whom were born into political freedom after 1994) has led me to the conviction that the use of the term "post-apartheid South Africa" is disingenuous. While persons have the "right to have rights", the rights themselves have not been concretised or realised in their everyday lives (Benhabib 2004: 50). I contend that it compounds the suffering of the poor and disenfranchised when we use language that suggests that their daily experience of reality is not valid or is unreal. In the context of our current discussion, it denies the memory and experience of our linguistic and ontological partner by placing upon them categories of meaning which are not their own - such as freedom, or the "post" in post-Apartheid South Africa. If we are to apply an ethics of linguistic and ontological hospitality, we should be willing to suspend such language, and allow it to be supplanted in the "exchange of memories", by "taking responsibility, in imagination and in sympathy, for the story of the other, through the life narratives which concern the other" (Ricoeur \& Brennan 1995: 6-7).

This exchange of memories, which moves from linguistic hospitality, to the ethics of narrative hospitality, allows for a reframing of what may be possible. Ricoeur refers to this as the dialectic "partnership of tradition and innovation" (Ricoeur \& Brennan 1995: 8). What is important in relation to innovation, is that it traverses time, (the past, the present, and the future). In the sharing of memories, one is able to discern past promises which have not been kept. While the past cannot be changed, one is able to see, in an innovative sense, what the intended trajectory of a promise (which was not kept) was towards the future. "The unfulfilled future of the past forms perhaps the richest part of tradition. The liberation of this unfulfilled future of the past is the major benefit that we can expect from the crossing of memories and the exchange of narratives" (Ricoeur \& Brennan 1995: 8).

In the exchange of what black Christians believe, and white Christians don't seem to understand, we can see some possibility for the future. If, as South Africans, we had the wisdom to opt for 'sense making', to live 
together in linguistic and ontological hospitality, we may just find that both the politics and the possibility of forgiveness could be realised.

The past is a cemetery of promises which have not been kept. It is a matter of bringing them back to life like the dry bones in the valley described in the prophecy of Ezekiel (Ch. 37). (Ricoeur \& Brennan 1995: 8).

In this sense, we can claim that forgiveness is both political and theological (spiritual) in nature, and that it is at the same time impossible, which makes it possible.

\section{On engagement between the self and the other - poetics and prose}

A crucial aspect of the political dimension of (im)possible forgiveness, as stated above, is the bringing back to life the unfulfilled promises of the past. For the sake of forgiveness, the exchange of memories inflicted and sustained "demands more than imagination and sympathy ... [it] consists in 'shattering the debt' [of the past]" (Ricoeur \& Brennan, 1995: 10). How can this be undertaken? As stated earlier, Ricoeur's philosophy of translation provides both hermeneutic and mediating possibilities.

\subsection{Translation and recognition of the (the self and the) other}

In the sense of translation as hermeneutics and mediation, forgiveness should be an act of authentic recognition of the self in relation to the other. The personal, emotional, response to the encounter with the other (hermeneutics) invites innovation and change. The encounter with the other offers an ethical challenge, an invitation, to the self (mediating forgiveness).

The question is, how will I respond to the exchange of memories? How will my understanding of the memory of the other, and my memory of myself, reshape how I move into the future? This is the beauty of the internal dialogue - it invites strangeness, it unsettles tradition, it questions convictions and beliefs. As Kearney points out, dialogue means exactly that dia-legien, "welcoming the difference" (Kearny in Ricoeur 2007b: xvii). In this act of welcoming difference (hospitality), a new set of possibilities emerges for the future. 
In relation to the context of this paper, it becomes clear that the future of forgiveness in South Africa is not binary - it is not only political, or only spiritual. Both black and white Christians are likely to grow thicker, more authentic, even shared, understandings of the concepts, processes and requirements for forgiveness through intentional and mutual engagement. While we cannot abolish the debt of our past through political aims, we can strive to "lift the pain" of the debt through our shared action and belief (Ricoeur \& Brennan 1995: 10). As Ricoeur suggests:

Forgiveness, in its full sense, certainly far exceeds political categories. It belongs to an order - the order of charity - which goes even beyond the order of morality. Forgiveness falls within the scope of an economy of the gift whose logic of superabundance exceeds the logic of reciprocity. (Ricoeur \& Brennan 1995: 10).

The important aspect to note in this quote is that the logic of the gift is not less than, but more than, reciprocity. In other words, it is not limited to, but rather surpasses, the pain of the past or the value of the present gift.

\subsection{The economy of the gift - poetics and prose}

Vosloo offers some insight into how such an approach can be understood in his discussion of Ricoeur's notion of recognition. Mutual recognition between the self and the other, he suggests, falls "between what he [Ricoeur] calls the prose of justice and the poetics of agape" (Vosloo 2015b: 3). We could write volumes on those two terms, justice and agape. However, for the purposes of this argument, we can simply state that justice is a sense of rightness, fairness, equity and neutrality between the self and other. While the Greek word, agape, refers to the highest, most selfless, forms of love and charity. The prose of justice and the poetics of agape are characteristics of the economy of the gift - indeed, as Vosloo states it, the mutual gift exchange. This is a "thicker moral language", according to Vosloo, since it deepens our understanding of the meaning of the ideal (agape) and the concrete (justice) (Vosloo 2015b: 3)".

Within the content of the research that framed this paper, there was a deliberate process of facilitating dialogue and engagement between the participants, and a critical reflection on the self. Indeed, as Ricoeur claimed, that "the best path to the self is through otherness" (Ricoeur 2007b: xviii). We worked carefully towards conceptual translation, and also ontological 
translation, in the encounters between the black and the white Christians. They gathered for a series of intercultural engagements in which they read and discussed texts of forgiveness. This was often a contested and volatile process. Yet, something of their commitment to the prose of justice and the poetics of agape unlocked a wonderful gift.

\section{Conclusion}

This paper argued for the development of an (im)possible politics of forgiveness for South Africa. Some time was taken to explicate understandings of the political in relation to forgiveness. A crucial aspect of this argument is that the political transactions are necessary, yet true forgiveness is not a transactional possibility. In a transactional sense it is impossible. The transaction is the beginning of forgiveness, not its end. It is a signifier of possibility, but not the possibility itself. In this regard it was argued that aspects of the philosophy of translation of Paul Ricoeur present both hermeneutical and mediating opportunities for the development of an (im)possible politics of forgiveness.

Does this mean that forgiveness is impossible in South Africa? Well, in some narrow senses, yes. However, as we discovered, by employing not only a hermeneutic of linguistic translation (conceptual discovery), but also a hermeneutic of ontological translation, we can move beyond the political confines of forgiveness to the (im)possible economy of the gift. In this sense, our mutual engagement allows for a bridge to be built between the prose of justice and the poetics of agape.

\section{Bibliography}

Adhikari, M. 2005. Not White Enough, Not Black Enough: Racial Identity in the South African Coloured Community. Athens, OH: Ohio University Press.

Alles het niet kom wôd deur Nathan Trantraal: 'n resensie. 2017. [Online]. Available: http://www.litnet.co.za/alles-het-niet-kom-wod-deur-nathan-trantraal-nresensie/ [Accessed: 2018, April 22].

Andrews, M. 1999. The Politics of Forgiveness. International Journal of Politics, Culture and Society. 13(1):107-124. 
Appiah, K.A. 2018. The Lies That Bind: Rethinking Identity. First edition. New York: Liveright.

Benhabib, S. 2004. The Rights of Others: Aliens, Residents, and Citizens. Cambridge University Press.

Bhabha, H.K. 2012. The Location of Culture. Routledge.

Van der Borght, E. 2009. [Online]. Available: https://research.vu.nl/files/2632701/ Oratie\%20Borght.pdf [Accessed: 2017, May 07].

Botha, J. \& Forster, D.A. 2017. Justice and the Missional Framework Document of the Dutch Reformed Church. Verbum et Ecclesia. 38(1):1-9.

Cakal, H., Hewstone, M., Schwär, G. \& Heath, A. 2011. An investigation of the social identity model of collective action and the 'sedative' effect of intergroup contact among Black and White students in South Africa. British Journal of Social Psychology. 50(4):606-627.

Derrida, J. 2007. A certain impossible possibility of saying the event. Critical Inquiry. 33(2):441-461.

Dube, S. 2017. Subjects of Modernity: Time-space, Disciplines, Margins. Oxford University Press.

Forster, D.A. 2010a. A generous ontology: Identity as a process of intersubjective discovery - An African theological contribution. HTS Teologiese Studies / Theological Studies. 66(1):1-12.

Forster, D.A. 2010b. African relational ontology, individual identity, and Christian theology An African theological contribution towards an integrated relational ontological identity. Theology. 113(874):243-253.

Forster, D.A. 2017a. The (im)possibility of forgiveness? An empirical intercultural Bible reading of Matthew 18:15-35. 1st ed. Vol. XI. (Beyers Naudé Centre Series on Public Theology). Stellenbosch, South Africa: SUN Press. [Online]. Available: http://www.africansunmedia.co.za/Sun-e-Shop/ Product-Details/tabid/78/ProductID/498/Default.aspx

Forster, D.A. 2017b. A public theological approach to the (im) possibility of forgiveness in Matthew 18.15-35: Reading the text through the lens of integral theory. In die Skriflig/In Luce Verbi. 51(3):1-10. 
Frost, B. 1991. The Politics of Peace. London: Darton, Longman and Todd. Fukuyama, F. 2018. Identity: The Demand for Dignity and the Politics of Resentment. London: MacMillan.

Gobodo-Madikizela, P. \& Merwe, C.V.D. 2009. Memory, Narrative and Forgiveness: Perspectives on the Unfinished Journeys of the Past.

Cambridge: Cambridge Scholars Publishing.

Hofmeyr, J.H. \& Govender, R. 2015. SA Reconciliation Barometer 2015: National Reconciliation, Race Relations, and Social Inclusion. Cape Town: Institute for Justice and Reconciliation. [Online]. Available: http://www.jir.org.za/uploads/JJR_SARB_2015_WEB_002.pdf

Janover, M. 2005. The Limits of Forgiveness and the Ends of Politics. Journal of Intercultural Studies. 26(3):221-235.

Kearney, R. 2007. Paul Ricoeur and the Hermeneutics of Translation. Research in phenomenology. 37(2):147.

Kearney, R. 2013. Forgiveness as the limit: Impossible or possible. In F. O’Rourke (ed.). Notre Dame, IN: University of Notre Dame Press What happened in and to moral philosophy in the twentieth century: Philosophical essays in honour of Alasdair Macintyre. 305-320.

Kearney, R. 2015. What is Carnal Hermeneutics? New Literary History. 46(1):99-124.

Mbembe, A. 2008. Passages to freedom: The politics of racial reconciliation in South Africa. Public Culture. 20(1):5-18.

Mbembe, A. 2015. Achille Mbembe on the State of South African Political Life. [Online]. Available: http://africasacountry.com/2015/09/achille-mbembe-onthe-state-of-south-african-politics/ [Accessed: 2016, January 02].

Nussbaum, M.C.C. 2010. Not For Profit: Why Democracy Needs the Humanities. Princeton, NJ: Princeton University Press.

Ricoeur, P. 2000. Can forgiveness heal? In H.J. Opdebeeck (ed.). Leuven:

Peeters. The Foundation and Application of Moral Philosophy:

Ricoeur's Ethical Order. 31-36. 
Ricoeur, P. 2004. The difficulty to forgive. In M. Junker-Kenny \& P.

Kenny (eds.). Münster: LIT Verlag. Memory, Narrativity, Self and the Challenge to Think God: The reception with Theology of the recent work of Paul Ricoeur. 6-18.

Ricoeur, P. 2007a. Introduction: Ricoeur's philosophy of translation. In On Translation. Translated by Eileen Brennan. New York: Routledge. vii-xx.

Ricoeur, P. 2007b. On translation. Routledge. [Online]. Available: https:// books.google.co.za/books?hl=en\&lr=\&id=QtR_AgAAQBAJ\&oi=fnd\&pg=PP1\&dq =ricouer+translation\&ots=yN_qXAFje5\&sig=NnXD7Zhe5vsNDxWbpM9MAu0zFvU [Accessed: 2015, March 11].

Ricoeur, P. 2009. Memory, History, Forgetting. Chicago, IL: University of Chicago Press.

Ricoeur, P. \& Brennan, E. 1995. Reflections on a new ethos for Europe. Philosophy \& social criticism. 21(5-6):3-13.

Schoeman, W.J. 2017. South African religious demography: The 2013 General Household Survey. HTS Teologiese Studies / Theological Studies. 73(2):1-7.

Shutte, A. 2009. Ubuntu as the African Ethical Vision. In African Ethics: An Anthology of Comparative and Applied Ethics. M.F. Murove (ed.). University of KwaZulu-Natal Press. 85-99.

Trantraal, N. 2017. Alles het niet kom wôd: 'n digbundel. Eerste uitgawe ed. Kaapstad: Kwela.

Vosloo, R. 2015a. Difficult Forgiveness? Engaging Paul Ricoeur on Public Forgiveness within the Context of Social Change in South Africa. International Journal of Public Theology. 9(3):360-378.

Vosloo, R. 2015b. Between the Prose of Justice and the Poetics of Love?

Reading Ricoeur on Mutual Recognition in the Light of Harmful Strategies of "Othering”. Études Ricoeuriennes / Ricoeur Studies. 6(2).

Vosloo, R.R. 2012. Traumatic memory, representation and forgiveness:

Some remarks in conversation with Antjie Krog's Country of My Skull. In die Skriflig. 46(1). 